\title{
PENGARUH FDR DAN NPF TERHADAP PROFITABILITAS BANK UMUM SYARIAH DI INDONESIA \\ (Studi Pada Bank Umum Syariah yang Terdaftar di Otoritas Jasa Keuangan Periode 2012-2019)
}

\author{
Qory Qurotulaeni* \\ Universitas Singaperbangsa Karawang \\ Wirman \\ Universitas Singaperbangsa Karawang
}

\begin{abstract}
This study aims to determine the effect of Financing to Deposit Ratio (FDR) and Non-Performing Financing (NPF) on Profitability (ROA) of Islamic Commercial Banks registered with the Financial Services Authority for the 2012-2019 period. Data analysis using multiple linear regression. The research method used is a descriptive quantitative approach. The sample used is 40 data, namely 5 Islamic Commercial Banks for a period of 10 years. Samples were taken using purposive sampling technique. Methods of data collection using documentation techniques. The results of this study indicate that FDR has no effect on Profitability (ROA). While NPF has an effect on Profitability (ROA). Simultaneously FDR and NPF affect profitability (ROA).
\end{abstract}

Keywords: FDR, NPF, ROA, Islamic Banking

Paper type: Research paper

*Corresponding author: 171063103048@student.unsika.ac.id

Received: January 18, 2018; Accepted: November 13, 2021; Available online: December, 04, 2021

Cite this document:

Qurotulaeni, Q., \& Wirman. (2021). Pengaruh FDR dan NPF terhadap Profitabilitas Bank Umum Syariah di Indonesia (Studi pada Bank Umum Syariah yang Terdaftar di Otoritas Jasa Keuangan Periode 2012-2019). Jurnal Masharif Al-Syariah: Jurnal Ekonomi dan Perbankan Syariah, 6(3), 586-602. doi:http://dx.doi.org/10.30651/jms.v6i3.7173

Copyright (C) 2021, Jurnal Masharif Al-Syariah: Jurnal Ekonomi dan Perbankan

Syariah

http://journal.um-surabaya.ac.id/index.php/Mas/index

This article is licensed under a Creative Commons Attribution-NonCommercial 4.0 International License. 


\begin{abstract}
Abstrak
Penelitian ini bertujuan untuk mengetahui pengaruh Financing to Deposit Ratio (FDR) dan Non Perfoming Financing (NPF) terhadap Profitabilitas (ROA) Bank Umum Syariah yang terdaftar di Otoritas Jasa Keuangan Periode 2012-2019. Data analisis menggunakan regresi linier berganda. Metode penelitian yang digunakan adalah penelitian deskriptif asosiatif pendekatan kuantitatif. Sampel yang digunakan sebanyak 40 data, yaitu 5 Bank Umum Syariah selama periode 10 tahun. Sampel diambil menggunakan teknik purposive sampling. Metode pengumpulan data menggunakan teknik dokumentasi. Hasil penelitian ini menunjukkan bahwa FDR tidak berpengaruh terhadap Profitabilitas (ROA). Sedangkan NPF berpengaruh terhadap Profitabilitas (ROA). Secara simultan FDR dan NPF berpengaruh terhadap profitabilitas (ROA)
\end{abstract}

Kata kunci: FDR, NPF, ROA, Bank Syariah

\title{
PENDAHULUAN
}

Perekonomian pasti ada hubungannya dengan keuangan dan perbankan. Baik buruknya pertumbuhan ekonomi tergantung dari baik buruknya keuangan negara dan peran perbankan. Perbankan di Indonesia mengalami perkembangan yang sangat pesat. Bank terbagi menjadi dua jenis, yaitu Bank Konvensional dan Bank Syariah. Kedua bank ini hampir sama, namun sistem operasinya saja yang berbeda.

Bank Konvensional menggunakan bunga, tetapi Bank Syariah menggunakan sistem bagi hasil. Jumlah Bank syariah di Indonesia menurut OJK adalah 195 bank yang terdiri dari BUS (Bank Umum Syariah), UUS (Unit Usaha Syariah) dan BPRS (Bank Pembiayaan Rakyat Syariah).

Perbankan syariah di Indonesia mengalami kemajuan yang pesat. Seperti yang tercatat pada laporan Bank Indonesia (BI) pada akhir 2005, profitabilitas perbankan syariah secara umum mencapai tingkat keuntungan sebesar $\operatorname{Rp} 238,6$ miliar, profitabilitas perbankan syariah meningkat sebesar Rp 76,3 miliar (47\%) dari tahun 2004. Bank syariah melakukan peningkatan profitabilitas setiap tahunnya. 
Cara agar profitabilitas naik adalah dengan meningkatkan sumber dana yang ditempuh dengan menghimpun dana dari masyarakat yang kemudian dananya disalurkan kembali kepada nasabah (Irmawati, 2014). Bank syariah menyalurkan dana yang diperoleh dari masyarakat dalam bentuk simpanan dan selanjutnya disalurkan melalui pembiayaan, sehingga nasabah dapat meningkatkan ekonomi mereka. Keuntungan pada bank syariah dapat dilihat melalui profitabilitas (laba). Fungsi dari rasio profitabilitas yaitu untuk meihat keberhasilan kinerja suatu bank serta melihat besarnya keuntungan yang didapat. Apabila kinerja bank baik maka laba pun akan memperoleh kenaikan, sebaliknya jika kinerja bank buruk maka perolehan laba pun akan menurun.

Salah satu ukuran profitabilitas suatu bank menurut Bank Indonesia yaitu Return On Asset (ROA). Ketika bank menyalurkan kredit, tentu akan dihadapkan dengan risiko. Indikator dari risiko kredit yaitu Non Performing Financing (NPF). Nilai NPF yang tinggi pada suatu bank cenderung kurang efisien. Namun jika nilai NPF pada suatu bank rendah, maka lebih efisien. FDR (Financing to Deposit Ratio) merupakan jumlah pembiayaan yang diberikan bank dengan dana yang diterima oleh bank. Jika nilai FDR semakin tinggi, maka likuiditas suatu bank akan semakin rendah. Hasil penelitian Nugraheni dan Alam (2014) menyatakan bahwa FDR berpengaruh positif terhadap ROA. Bertentagan dengan penelitian yang dilakukan oleh Armereo (2015) yang menyatakan bahwa FDR berpengaruh negatif terhadap ROA.

\section{KAJIAN PUSTAKA DAN PENGEMBANGAN HIPOTESIS}

\section{Pengertian Bank Umum}

Menurut Undang-undang No. 10 Tahun 1998, Bank umum didefinisikan sebagai bank yang melaksanakan kegiatan usaha secara konvensional dan atau berdasarkan prinsip syariah yang dalam kegiatannya memberikan jasa dalam lalu lintas pembayaran. Kegiatan usaha yang dilakukan bank umum yaitu: 
a. Menghimpun dana dari masyarakat berupa giro, deposito berjangka, sertifikat deposito, tabungan dan atau bentuk lainnya yang dipersamakan dengan itu.

b. Memberikan kredit

c. Menerbitkan surat pengakuan utang

d. Membeli, menjual atau menjamin atas risiko sendiri maupun untuk kepentingan dan atas perintah nasabahnya

e. Memindahkan uang baik untuk kepentingan sendiri maupun untuk kepentingan nasabah

\section{Pengertian Bank Syariah}

Dalam UU No. 21 tahun 2008 mengenai perbankan syariah mengemukakan pengertian perbankan syariah dan pengertian bank syariah. Perbankan syariah yaitu segala sesuatu yang menyangkut bank syariah dan unit usaha syariah, mencakkup kelembagaan, kegiatan usaha, dan tata cata serta proses didalam pelaksanaan kegiatan usahanya. Sedangkan bank syariah adalah bank yang menjalankan kegiatan usahanya dengan didasarkan pada prinsip syariah dan menurut jenisnya bank syariah terdiri dari BUS (Bank Umum Syariah), UUS (Unit Usaha Syariah) dan BPRS (Bank Pembiayaan Rakyat Syariah).

Fungsi bank syariah yaitu:

1. Sebagai badan usaha, bertugas untuk menghimpun dana, menyalurkan dana dan menyediakan jasa keuangan atau non keuangan.

2. Sebagai badan sosial, bertugas untuk pengimpunan dan penyaluran zakat serta menyalurkan dana pinjaman kebajikan (Ascarya dan Yumanita, 2005:13).

\section{Financing to Deposit Ratio (FDR)}

Financing to Deposit Ratio (FDR) digunakan untuk mengukur kemampuan sebuah bank dalam membayar hutang jangka pendeknya dan membayar kembali kepada deposannya, serta memenuhi permintaan kredit yang diajukan oleh masyarakat secara tepat waktu. Dalam menunjukkan kemampuan perbankan, FDR dapat menyalurkan dana 
kepada debitur sekaligus membayarkam kembali kepada deposan dengan mengandalkan kredit yang disalurkan sebagai sumber likuiditas.

Menurut Bank Indonesia, standar besarnya nilai FDR yaitu antara $80 \%-110 \%$. Bila nilai FDR tinggi maka penyaluran dana untuk pembiayaan semakin besar, sehingga diharapkan dapat meningkatkan profitabilitas (ROA) Bank Syariah. FDR dapat dihitung dengan menggunakan rumus sebagai berikut:

$$
\mathrm{FDR}=\frac{\text { Pembiayaan }}{\text { Dana Pihak Ketiga }} \times 100 \%
$$

\section{Non Performing Financing (NPF)}

Istilah Non Performing Loan (NPL) dalam Bank Syariah diganti menjadi Non Performing Financing (NPF), karena dalam bank syariah menggunakan prinsip pembiayaan. Risiko kredit dapat diukur dengan rasio Non Peforming Financing (NPF). Bank Indonesia menetapkan besarnya NPF yang baik adalah dibawah $5 \%$. Bila nilai NPF besar, maka akan memperkecil profitabilitas bank karena dana yang tidak dapat ditagih menyebabkan bank tidak dapat melakukan pembiayaaan. Sehingga, pendapatan bank menjadi berkurang dan profitabilitas perbankan akan terganggu.

Berdasarkan Surat Edaran Bank Indonesia Nomor 9/29/DPbs tanggal 7 Desember 2007, cara menghitung NPF yaitu dengan membandingkan jumlah pembiayaan bermasalah dengan total pembiayaan yang dimiliki oleh bank. Menurut Bank Indonesia terdapat tiga macam pembiayaan bermasalah, yaitu kurang lancar, diragukan, dan macet. Adapun rumus NPF yaitu:

$$
\mathrm{NPF}=\frac{\text { Pembiayaan Bermasalah }}{\text { Total Pembiayaan }} \times 100 \%
$$

\section{Return On Asset (ROA)}

Indikator untuk mengukur efisiensi perusahaan dalam menghasilkan keuntungan dengan menggunakan Return On Asset (ROA). Rasio ini 
memberikan ukuran tingkat efektivitas manajemen suatu bank yang ditunjukkan oleh laba yang dihasilkan dari penjualan dan pendapatan investasi (Kasmir, 2015). ROA merupakan rasio yang menunjukkan hasil atas jumlah aktiva yang digunakan dalam bank (Kasmir, 2011). Menurut Bank Indonesia, ROA > 1,22\% dinilai sehat, 0,99-1,22\% cukup sehat, dan $<0,77 \%$ kurang sehat. Berdasarkan Surat Edaran Bank Indonesia Nomor 9/29/DPbs tanggal 7 Desember 2007, ROA dirumuskan sebagai berikut:

$\mathrm{ROA}=\frac{\text { Laba Sebelum Pajak }}{\text { Total Asset }} \times 100 \%$

\section{Kerangka Pemikiran}

Dalam penelitian ini, kerangka pemikiran dibuat agar mempermudah dalam memahami hubungan antara Financing to Deposit Ratio (FDR) dan Non Performing Financing (NPF) terhadap Profitabilitas (ROA).

\section{Gambar 2.1}

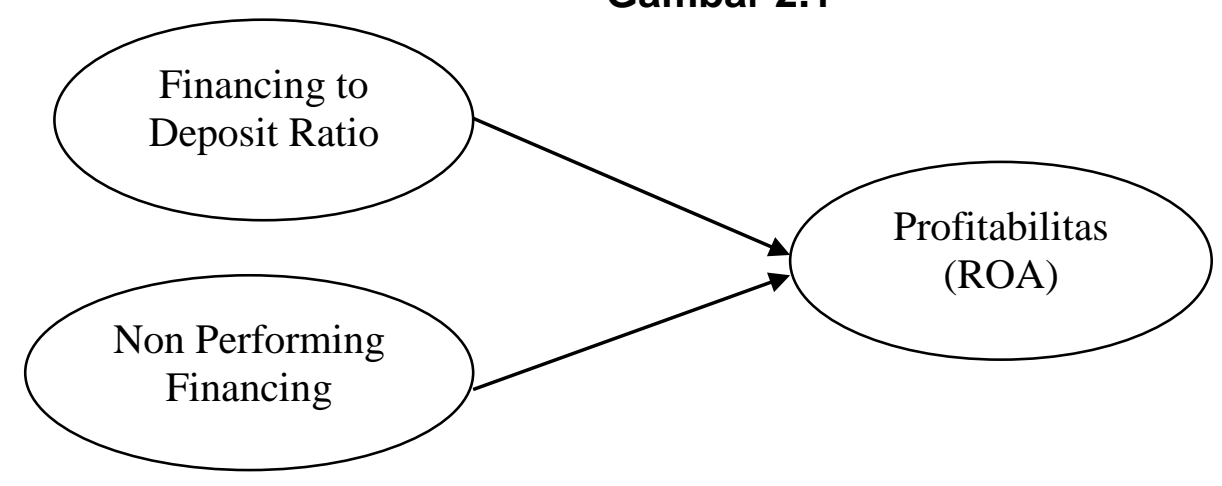

\section{Hipotesis}

Menurut Sugiyono (2015:64) hipotesis merupakan jawaban sementara terhadap rumusan masalah penelitian. Dikatakan sementara karena jawaban yang diberikan baru didasarkan pada teori yang relevan, belum didasarkan pada fakta-fakta empiris yang diperoleh melalui pengumpulan data. Hipotesis dalam penelitian ini yaitu:

H1: Terdapat pengaruh Financing to Deposit Ratio (FDR) terhadap ROA pada Bank Umum Syariah yang terdaftar di Otoritas Jasa Keuangan. 
H2: Terdapat pengaruh Non Performing Financing (NPF) terhadap ROA pada Bank Umum Syariah yang terdaftar di Otoritas Jasa Keuangan.

H3: Terdapat pengaruh FDR dan NPF terhadap ROA pada Bank Umum Syariah yang terdaftar di Otoritas Jasa Keuangan.

\section{METODE PENELITIAN}

\section{Jenis dan Sumber Data}

Jenis penelitian yang digunakan adalah penelitian deskriptif dengan pendekatan kuantitatif. Variabel yang digunakan adalah variabel bebas (independen) meliputi Financing to Deposit Ratio (FDR) dan Non Performing Loan (NPL), serta variabel terikat (dependen) yaitu profitabilitas (ROA). Sumber data yang digunakan yaitu data sekunder yang diperoleh dari website www.ojk.go.id. Teknik pengambilan sampel menggunakan teknik purposive sampling. Sampel yang digunakan sebanyak 40 data meliputi 5 Bank Umum Syariah dalam 8 tahun periode. Teknik pengumpulan data menggunakan teknik dokumentasi berupa data laporan tahunan Bank Umum Syariah dari website www.ojk.go.id. Metode yang digunakan adalah metode analisis linier berganda dalam uji asumsi klasik (uji normalitas, heteroskedastisidas, multikolinieritas, autokorelasi), serta uji signifikansi (uji t, uji f, dan koefisien determinasi).

\section{Populasi}

Dalam penelitian ini, yang menjadi populasi penelitian adalah seluruh Bank Umum Syariah yang terdaftar di Otoritas Jasa Keuangan hingga tahun 2019. Adapun jumlah perusahaan yang menjadi populasi dalam penelitian ini adalah 14 perusahaan. Jumlah tersebut merupakan jumlah seluruh populasi didalam penelitian. Untuk itu, populasi didalam penelitian ini digeneralisasikan sebagai objek langsung yang amati selama penelitian berlangsung.

\section{Sampel}

Sampel yang digunakan dalam penelitian ini yaitu sebanyak 5 bank. Adapun jenis pengambilan sampel pada penelitian ini adalah meggunakan Nonprobabillity Sampling dengan pendekatan purposive sampling. non probability sampling yaitu teknik pengambilan sampel yang tidak 
memberikan peluang atau kesempatan sama bagi setiap unsur atau anggota populasi untuk dipilih menjadi sampel dengan menggunakan pendekatan purposive sampling. Purposive sampling adalah teknik penentuan sampel dengan pertimbangan tertentu. Oleh karena itu, diperoleh sampel sebanyak 5 Bank Umum Syariah yang terdaftar di Otoritas Jasa Keuangan (OJK) sebagai berikut:

Tabel 3.1

Daftar Sampel Bank Umum Syariah

\begin{tabular}{|l|l|}
\hline No & \multicolumn{1}{|c|}{ Nama Perusahaan } \\
\hline 1 & PT Bank BNI Syariah \\
\hline 2 & PT Bank BRI Syariah \\
\hline 3 & PT Bank BCA Syariah \\
\hline 4 & PT Bank Mega Syariah \\
\hline 5 & PT Bank Syariah Bukopin \\
\hline
\end{tabular}

\section{Definisi Operasional}

Menurut Sugiyono (2015, h 38) definisi operasional adalah suatu atribut atau sifat atau nilai dari obyek atau kegiatan yang memiliki variasi tertentu yang telah ditetapkan oleh peneliti untuk dipelajari dan kemudian ditarik kesimpulannya. Dalam penelitian ini, definisi operasional dari variabel Financing to Deposit Ratio (FDR), Non Permorfming Financing (NPF) dan Returrn On Asset (ROA) adalah sebagai berikut:

1. Financing to Deposit Ratio (FDR)

Financing to Deposit Ratio (FDR) digunakan untuk mengukur kemampuan sebuah bank dalam membayar hutang jangka pendeknya dan membayar kembali kepada deposannya, serta memenuhi permintaan kredit yang diajukan oleh masyarakat secara tepat waktu. Rumus untuk mencari FDR sebagai berikut:

$\mathrm{FDR}=\frac{\text { Pembiayaan }}{\text { Dana Pihak Ketiga }} \times 100 \%$ 
2. Non Permorfming Financing (NPF)

Non Performing Financing (NPF) yaitu pembiayaan bermasalah yang dialami oleh bank, pembiayaan bermasalah ini jelas akan mempengaruhi kinerja bank sebagai lembaga keuangan dan akan berdampak pada laba yang diperoleh bank.

Untuk menghitung CAR menggunakan rumus:

NPF $=\frac{\text { Pembiayaan Bermasalah }}{\text { Total Pembiayaan }} \times 100 \%$

\section{Returrn On Asset (ROA)}

Rasio ini memberikan ukuran tingkat efektivitas manajemen suatu bank yang ditunjukkan oleh laba yang dihasilkan dari penjualan dan pendapatan investasi (Kasmir, 2015).

$$
\mathrm{ROA}=\frac{\text { Laba Sebelum Pajak }}{\text { Total Asset }} \times 100 \%
$$

\section{HASIL DAN PEMBAHASAN}

\section{Hasil Penelitian}

Untuk mengetahui, menjelaskan dan menganalisis Financing to Deposit Ratio (FDR), Non Performing Financing (NPF) dan Return On Assets (ROA) pada Bank Umum Syariah Di Indonesia yang terdaftar di Otoritas Jasa Keuangan (OJK) maka dilakukan analisis deskriptif, uji asumsi klasik, analisis regresi linear berganda dan uji hipotesis yaitu sebagai berikut. 
Analisis Deskriptif

Descriptive Statistics

\begin{tabular}{|l|r|r|r|r|r|}
\hline & $\mathrm{N}$ & Minimum & $\begin{array}{c}\text { Maximu } \\
\mathrm{m}\end{array}$ & Mean & $\begin{array}{c}\text { Std. } \\
\text { Deviation }\end{array}$ \\
\hline FDR & 40 & 74.31 & 102.70 & 89.8190 & 6.28595 \\
NPF & 40 & .10 & 7.85 & 3.0702 & 1.93589 \\
ROA & 40 & -1.00 & 3.81 & 1.0305 & .80224 \\
Valid N & 40 & & & & \\
(listwise) & 40 & & & & \\
\hline
\end{tabular}

Tabel analisis deskriptif diatas menunjukkan bahwa sampel yang digunakan dalam penelitian ini berjumlah 40. Diketahui bahwa variabel ROA memiliki nilai rata-rata (mean) sebesar 1,0305, pada variabel FDR menunjukkan rata-rata sebesar 89,82. Hal ini menunjukkan bahwa FDR termasuk dalam kategori yang sehat karena ketentuan Bank Indonesia yaitu $85 \%$ sampai dengan $110 \%$. Pada variabel NPF terlihat 3,07.

\section{Uji Asumsi Klasik}

\section{Uji Normalitas Data}

One-Sample Kolmogorov-Smirnov Test

\begin{tabular}{|c|c|c|}
\hline & Unstandardized Residual \\
\hline \multicolumn{2}{|l|}{$\mathrm{N}$} & 40 \\
\hline \multirow[t]{2}{*}{ Normal Parameters ${ }^{a}$} & Mean & .0000000 \\
\hline & Std. Deviation & .70601898 \\
\hline \multirow{3}{*}{$\begin{array}{l}\text { Most Extreme } \\
\text { Differences }\end{array}$} & Absolute & 136 \\
\hline & Positive & .136 \\
\hline & Negative & -.107 \\
\hline \multicolumn{2}{|l|}{ Kolmogorov-Smirnov Z } & .861 \\
\hline \multicolumn{2}{|l|}{ Asymp. Sig. (2-tailed) } & .448 \\
\hline \multicolumn{2}{|c|}{ a. Test distribution is Normal. } & \\
\hline
\end{tabular}

Dari hasil yang dilihat pada tabel diatas dapat diketahui bahwa nilai signifikansi Asymp.sig. (2-tailed) adalah sebesar 0,448 yang artinya lebih 
besar dibandingkan dengan 0,05 . Hal ini dapat diartikan bahwa asumsi uji normalitas telah terpenuhi dan data residual berdistribusi normal.

\section{Uji Multikolinieritas}

\begin{tabular}{|c|c|c|c|}
\hline \multicolumn{4}{|c|}{ Coefficients $^{a}$} \\
\hline \multirow{2}{*}{\multicolumn{2}{|c|}{ Model }} & \multicolumn{2}{|c|}{$\begin{array}{l}\text { Collinearity } \\
\text { Statistics }\end{array}$} \\
\hline & & $\begin{array}{c}\text { Toleranc } \\
\mathrm{e}\end{array}$ & VIF \\
\hline 1 & FDR & .998 & 1.002 \\
\hline & NPF & .998 & 1.002 \\
\hline
\end{tabular}

a. Dependent Variable: ROA

Berdasarkan hasil uji multikolinieritas maka diperoleh nilai Tolerance untuk variabel FDR (X1) dan NPF (X2) berada diangka 0,998 yang artinya nilai tersebut lebih dari 0,1. Sedangkan nilai VIF FDR (X1) dan NPF (X2) berada diangka 1,002 yang artinya, nilai ini kurang dari 10, sehingga model regresi bebas dari multikolinieritas antar variabel independen.

Uji Heteroskedastisitas

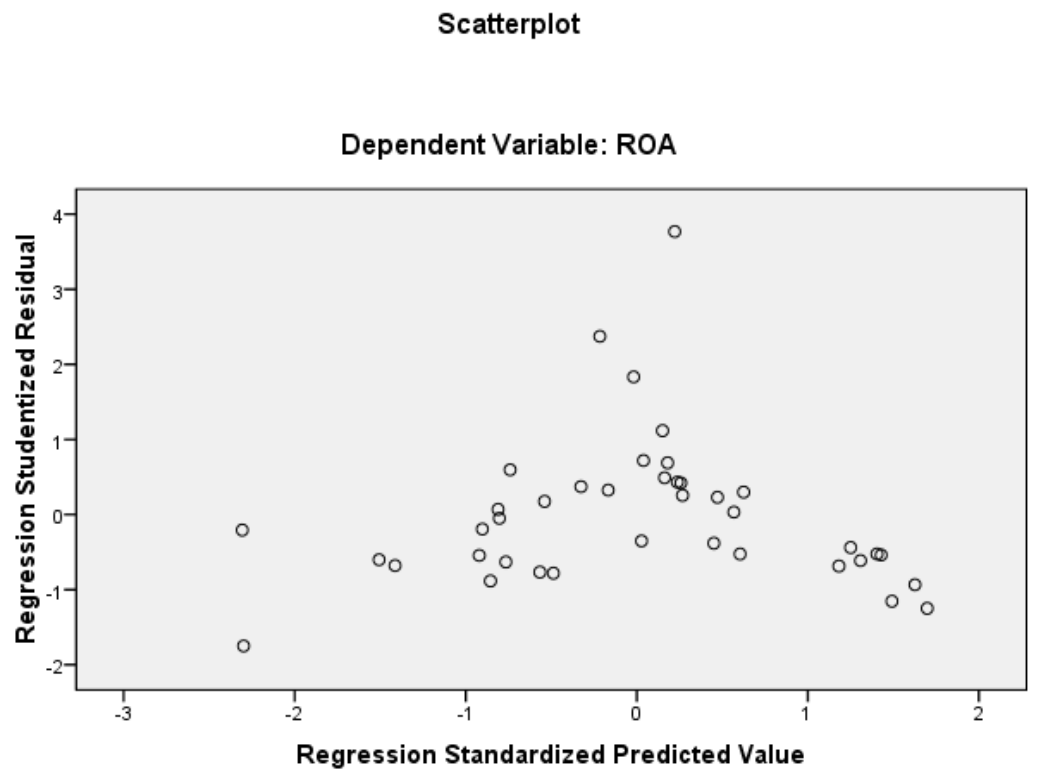

Bedasarkan gambar diatas pada grafik Scatterplot dapat dilihat bahwa titik-titik yang menyebar secara acak baik diatas maupun dibawah 
angka nol dan tidak membentuk pola tertentu. Dengan demikian dapat disimpulkan bahwa tidak terjadi heteroskedastisitas dalam penelitian ini.

\section{Uji Autokorelasi}

\begin{tabular}{|l|c|r|r|r|r|}
\hline Model Summary \\
Model & $\mathrm{R}$ & $\begin{array}{c}\mathrm{R} \\
\text { Square }\end{array}$ & $\begin{array}{c}\text { Adjusted R } \\
\text { Square }\end{array}$ & $\begin{array}{c}\text { Std. Error of } \\
\text { the Estimate }\end{array}$ & $\begin{array}{c}\text { Durbin- } \\
\text { Watson }\end{array}$ \\
\hline 1 & $.475^{\mathrm{a}}$ & .226 & .184 & .72485 & 1.371 \\
\hline
\end{tabular}

a. Predictors: (Constant), NPF, FDR

b. Dependent Variable: ROA

Berdasarkan hasil tabel autokorelasi, menunjukkan nilai Durbin Watson sebesar 1,371 terletak diantara -2 dan +2 yang artinya tidak terjadi autokorelasi.

\section{Analisis Regresi Berganda}

\section{Coefficients $^{\mathrm{a}}$}

\begin{tabular}{|c|c|c|c|c|c|c|}
\hline \multirow{2}{*}{\multicolumn{2}{|c|}{ Model }} & \multicolumn{2}{|c|}{$\begin{array}{c}\text { Unstandardized } \\
\text { Coefficients }\end{array}$} & \multirow{2}{*}{ 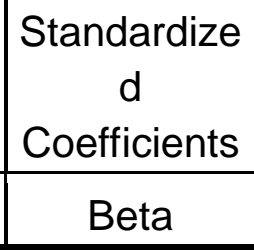 } & \multirow[b]{2}{*}{$\mathrm{t}$} & \multirow[b]{2}{*}{ Sig. } \\
\hline & & B & Std. Error & & & \\
\hline \multirow[t]{3}{*}{1} & (Constant) & 2.252 & 1.666 & & 1.351 & .185 \\
\hline & FDR & -.007 & .018 & -.054 & -.376 & .709 \\
\hline & NPF & -.195 & .060 & -.469 & -3.242 & .003 \\
\hline
\end{tabular}

a. Dependent Variable: ROA

Berdasarkan hasil analisis regresi linier berganda pada tabel diatas, maka dapat diketahui bahwa nilai konstanta sebesar 2,252. Koefisien regresi FDR terhadap Profitabilitas (ROA) sebesar -0,007, koefisien regresi NPF terhadap Profitabilitas (ROA) sebesar -0,195. Dari hasil tersebut dapat diperoleh persamaan analisis linier berganda sebagai berikut:

$Y=2,252+-0,007+-0,195+e$ 


\section{Uji Hipotesis}

Uji Signifikansi Parameter Individual (uji t)

\begin{tabular}{|c|c|c|c|c|c|c|}
\hline \multicolumn{7}{|c|}{ Coefficients $^{a}$} \\
\hline \multirow{2}{*}{\multicolumn{2}{|c|}{ Model }} & \multicolumn{2}{|c|}{$\begin{array}{l}\text { Unstandardized } \\
\text { Coefficients }\end{array}$} & \multirow{2}{*}{$\begin{array}{c}\begin{array}{c}\text { Standardize } \\
d \\
\text { Coefficients }\end{array} \\
\text { Beta } \\
\end{array}$} & \multirow[b]{2}{*}{$\mathrm{t}$} & \multirow[b]{2}{*}{ Sig. } \\
\hline & & B & Std. Error & & & \\
\hline & (Constant & 2.252 & 1.666 & & 1.351 & .185 \\
\hline & FDR & -.007 & .018 & -.054 & -.376 & .709 \\
\hline & NPF & -.195 & .060 & -.469 & -3.242 & .003 \\
\hline
\end{tabular}

a. Dependent Variable: ROA

Dengan menggunakan tingkat signifikansi $5 \%$ dan menguji 2 sisi diperoleh nilai t tabel $(\mathrm{df})=(n-k)=40-3=37$ yaitu sebesar 2,026. Dari tabel diatas maka analisis regresi berganda dapat menganalisis masingmasing variabel yaitu FDR, dan NPL terhadap Profitabilitas (ROA) sebagai berikut:

\section{Pengaruh FDR terhadap Profitabilitas (ROA)}

Berdasarkan hasil pengujian untuk variabel $\mathrm{X} 1$ yaitu FDR diperoleh nilai t hitung sebesar $-0,376$. Jika dibandingkan dengan nilai $t$ tabel yaitu sebesar 2,026 sehingga nilai $\mathrm{t}$ hitung $<\mathrm{t}$ tabel. Sedangkan nilai signifikansinya yaitu sebesar 0,709 lebih besar dari 0,05 atau 0,709> 0,05. Jadi, dapat disimpulkan bahwa $\mathrm{HO}$ diterima dan Ha ditolak. Artinya, secara parsial variabel FDR tidak berpengaruh terhadap variabel Profitabilitas (ROA).

\section{Pengaruh NPF terhadap Profitabilitas (ROA)}

Berdasarkan hasil pengujian untuk variabel X2 yaitu NPF diperoleh nilai $t$ hitung sebesar $-3,242$. Jika dibandingkan dengan nilai $t$ tabel yaitu sebesar 2,026 sehingga nilai $\mathrm{t}$ hitung $>\mathrm{t}$ tabel. Sedangkan nilai signifikansinya yaitu sebesar 0,003 lebih kecil dari 0,05 atau 0,003 0,05. Jadi, dapat disimpulkan bahwa $\mathrm{HO}$ ditolak dan Ha diterima. Artinya, secara parsial variabel NPF berpengaruh terhadap variabel Profitabilitas (ROA).

Uji Signifikan Simultan (uji f) 
ANOVA $^{b}$

\begin{tabular}{|l|r|r|r|r|r|}
\hline Model & \multicolumn{1}{|c|}{$\begin{array}{c}\text { Sum of } \\
\text { Squares }\end{array}$} & \multicolumn{1}{c|}{ df } & \multicolumn{1}{c|}{$\begin{array}{c}\text { Mean } \\
\text { Square }\end{array}$} & \multicolumn{1}{c|}{$\mathrm{F}$} & \multicolumn{1}{c|}{ Sig. } \\
\hline $1 \quad$ Regressio & 5.660 & 2 & 2.830 & 5.386 & $.009 \mathrm{a}$ \\
$\mathrm{n}$ & 19.440 & 37 & .525 & & \\
Residual & 25.100 & 39 & & & \\
\hline Total & & & & \\
\hline
\end{tabular}

a. Predictors: (Constant), NPF, FDR

b. Dependent Variable: ROA

Berdasarkan hasil uji $\mathrm{F}$ dapat diketahui bahwa variabel independen memiliki pengaruh yang signifikan terhadap variabel dependen. Hal ini dapat dibuktikan dari nilai $f$ hitung sebesar 5,386 . Derajat bebas df1 $=k-1$ dan df2 $=n-k$ atau df1 $=3-1=2$ dan df2 $=40-3=37$, diperoleh angka $f$ tabel sebesar 3,25. Sehingga diperoleh nilai 5,386 $>3,25$ atau $f$ hitung $>f$ tabel. Sedangkan nilai signifikansi sebesar 0,009 lebih kecil dari 0,05. Sehingga HO ditolak dan Ha diterima. Dapat disimpulkan bahwa terdapat pengaruh terhadap variabel independen yaitu FDR, dan NPF terhadap variabel dependen Profitabilitas $(\mathrm{ROA})$.

Koefisien Determinasi

\begin{tabular}{|c|c|c|c|c|c|}
\hline \multicolumn{6}{|c|}{ Model Summaryb } \\
\hline Model & $\mathrm{R}$ & $\begin{array}{c}\mathrm{R} \\
\text { Square }\end{array}$ & $\begin{array}{l}\text { Adjusted R } \\
\text { Square }\end{array}$ & $\begin{array}{c}\text { Std. Error of } \\
\text { the Estimate }\end{array}$ & $\begin{array}{l}\text { Durbin- } \\
\text { Watson }\end{array}$ \\
\hline 1 & $.475^{\mathrm{a}}$ & .226 & .184 & .72485 & 1.371 \\
\hline
\end{tabular}

a. Predictors: (Constant), NPF, FDR

b. Dependent Variable: ROA

Dari hasil pengujian pada tabel diatas dapat diketahui bahwa koefisien determinasi atau $\mathrm{R}$ Square sebesar 0,226 atau 22,6\%. Hal ini menunjukkan bahwa variabel yang diteliti yaitu FDR, dan NPF berpengaruh sebesar 22,6\% terhadap Profitabilitas (ROA). Sedangkan sisanya yaitu sebesar $77,4 \%$ dipengaruhi oleh variabel lain yang tidak diteliti dalam penelitian ini. 


\section{Pembahasan}

\section{Pengaruh FDR terhadap Profitabilitas (ROA)}

Berdasarkan hasil pengujian untuk variabel X1 yaitu FDR diperoleh nilai t hitung sebesar $-0,376$. Jika dibandingkan dengan nilai t tabel yaitu sebesar 2,026 sehingga nilai $t$ hitung < t tabel. Sedangkan nilai signifikansinya yaitu sebesar 0,709 lebih besar dari 0,05 atau 0,709 > 0,05. Jadi, dapat disimpulkan bahwa HO diterima dan Ha ditolak. Artinya, secara parsial variabel FDR tidak berpengaruh terhadap variabel Profitabilitas (ROA).

Berdasarkan hasil uji yang telah dilakukan, FDR tidak berpengaruh terhadap Profitabilitas (ROA). Hal ini juga sama dengan penelitian yang dilakukan oleh Misbahul Munir (2018) yang menyatakan bahwa FDR tidak berpengaruh terhadap ROA.

\section{Pengaruh NPF terhadap Profitabilitas (ROA)}

Berdasarkan hasil pengujian untuk variabel X2 yaitu NPF diperoleh nilai t hitung sebesar -3,242. Jika dibandingkan dengan nilai t tabel yaitu sebesar 2,026 sehingga nilai $t$ hitung $>t$ tabel. Sedangkan nilai signifikansinya yaitu sebesar 0,003 lebih kecil dari 0,05 atau 0,003< 0,05. Jadi, dapat disimpulkan bahwa $\mathrm{HO}$ ditolak dan Ha diterima. Artinya, secara parsial variabel NPF berpengaruh terhadap variabel Profitabilitas (ROA).

Berdasarkan hasil uji yang telah dilakukan, NPF berpengaruh terhadap Profitabilitas (ROA). Hal ini juga sama dengan penelitian yang dilakukan oleh Yuwita Ariessa Pravasanti (2018) yang menyatakan bahwa NPF berpengaruh terhadap ROA. Semakin besar NPF akan berdampak pada penurunan Profitabilitas. Bila NPF tinggi, semakin tinggi pula kerugian yang dialami oleh bank.

\section{Pengaruh FDR dan NPF terhadap Profitabilitas (ROA)}

Berdasarkan hasil uji f diketahui bahwa secara bersama-sama variabel independen mempunyai pengaruh yang signifikan terhadap variabel dependen. Hal ini dapat dibuktikan dari nilai $f$ hitung sebesar 5,386 . Derajat bebas $\mathrm{df} 1=\mathrm{k}-1$ dan $\mathrm{df} 2=\mathrm{n}-\mathrm{k}$ atau df1 $=3-1=2$ dan df2 $=$ 40-3 = 37, diperoleh angka f tabel sebesar 3,25. Sehingga diperoleh nilai 
$5,386>3,25$ atau $f$ hitung $>f$ tabel. Sedangkan nilai signifikansi sebesar 0,009 lebih kecil dari 0,05. Sehingga HO ditolak dan Ha diterima. Dapat disimpulkan bahwa terdapat pengaruh terhadap variabel independen yaitu FDR, dan NPF terhadap variabel dependen Profitabilitas (ROA).

Berdasarkan hasil pengujian nilai koefisien determinasi atau $R^{2}$ sebesar 0,226 atau 22,6\%. Hal ini menunjukkan bahwa variabel yang diteliti yaitu Likuiditas (LDR), dan Kecukupan Modal (CAR) berpengaruh sebesar 22,6\% terhadap Profitabilitas (ROA). Sedangkan sisanya $77,4 \%$ dipengaruhi oleh variabel yang tidak diteliti dalam penelitian ini. Dengan demikian terdapat pengaruh dari FDR, dan NPF sebesar 22,6\% terhadap Profitabilitas (ROA) pada Perusahaan Bank Umum Syariah yang terdaftar di Otoritas Jasa Keuangan (OJK) Periode 2012-2019.

\section{KESIMPULAN DAN SARAN}

\section{Kesimpulan}

Berdasarkan hasil penelitian yang dilakukan, secara parsial variabel FDR tidak berpengaruh terhadap variabel Profitabilitas (ROA). Sebaliknya, secara parsial variabel NPF berpengaruh terhadap variabel Profitabilitas $(R O A)$. Nilai NPF yang tinggi pada suatu bank cenderung kurang efisien. Namun jika nilai NPF pada suatu bank rendah, maka lebih efisien. Sedangkan secara simultan terdapat pengaruh terhadap variabel independen yaitu FDR, dan NPF terhadap variabel dependen Profitabilitas (ROA).

\section{Saran}

1. Perbankan sebaiknya mempertimbangkan faktor FDR, dan NPF dalam konteks pencapaian tingkat laba untuk mendapatkan profitabilitas bank yang semakin baik untuk kedepannya.

2. Penulis menyadari bahwa dalam penelitian ini masih banyak kekurangan dan keterbatasan baik dalam variabel FDR maupun NPF. Oleh karena itu diperlukan ruang lingkup yang lebih luas dalam peneltian selanjutnya dengan cara menambah variabel penelitian yang dapat mempengaruhi profitabilitas $(R O A)$ serta dapat dilakukan 
penelitian terhadap bank-bank lainnya yang mana setiap bank akan berbeda data keuangan dan hasilnya.

\section{DAFTAR PUSTAKA}

Kasmir, (2012). Bank dan Lembaga Keuangan Lainnya. Jakarta: PT. Raja Grafindo. Persada

Otoritas Jasa Keuangan. Laporan Keuangan Tahun 2012-2019.

http://www.ojk.go.id.

https://www.syariahbukopin.co.id/id/laporan

https://www.bnisyariah.co.id/id-

$\mathrm{id} /$ perusahaan/hubunganinvestor/laporanpresentasi/laporantahunan

https://ir-brisyariah.com/annual_reports.html

https://www.bcasyariah.co.id/laporan-keuangan/tahunan/2019-3/

www.megasyariah.co.id

Slamet Riyadi, Agung Yulianto (2014). Pengaruh Pembiayaan Bagi Hasil, Pembiayaan Jual Beli, Financing to Deposit Ratio (FDR) dan Non Performing Financing (NPF) Terhadap Profitabilitas Bank Umum Syariah di Indonesia

Misbahul Munir (2018). Analisis Pengaruh CAR, NPF, FDR, dan Inflasi Terhadap Profitabilitas Perbankan Syariah di Indonesia 